\title{
Liquidity and The Profitability of Manufacturing Firms in Nigeria
}

\author{
Gideon Tayo AKINLEYE ${ }^{1} \&$ Joseph Segun OGUNLEYE ${ }^{2}$ \\ ${ }^{1}$ Ph.D., Department of Accounting, Faculty of Management Sciences, Ekiti State University, Ado Ekiti, Nigeria \\ ${ }^{2}$ Department of Accounting, Faculty of Management Sciences, Ekiti State University, Ado Ekiti, Nigeria \\ Correspondence: Joseph Segun OGUNLEYE, Nigeria. E-mail: segun.ogunleye@ fuoye.edu.ng
}

Received: June 24, 2019

Accepted: August 16, 2019

Available online: August 26, 2019

doi:10.11114/afa.v5i2.4477

URL: https://doi.org/10.11114/afa.v5i2.4477

\begin{abstract}
This study examined the relationship between liquidity and profitability of manufacturing firms in Nigeria. The study specifically analyzed the effect of cash ratio, current ratio and quick ratio on profit after tax of the manufacturing firms in Nigeria. Secondary data were collected from annual reports of sampled firms over a period of ten years (2007-2016) and were analyzed using panel data estimators such as pooled OLS estimator, fixed effect estimator, random effect estimator, Hausman test, panel co-integration and pooled granger causality tests. The findings revealed that financial liquidity proxy in terms of quick ratio $(\mathrm{QR})$ had a negative and insignificant impact on profit after tax with coefficient estimate of $-0.094121(\mathrm{p}=0.2247>0.05)$. Financial liquidity measured in terms of Cash ratio (CR) exert positive and significant impact on profit after tax with coefficient estimate of $0.379774(\mathrm{p}=0.0121<0.05)$. Result also showed that financial liquidity measured in terms of Current ratio (CNR) exert insignificant negative impact on profit after tax with coefficient estimate of $-0.024989(\mathrm{p}=0.1163>0.05)$. Meanwhile the study revealed that quick ratio $(\mathrm{QR})$, cash ratio (CR) and current ratio (CNR) has 0.581533 (58.1\%) variation in profit after tax (PAT). Result further revealed that that there is no long-run relationship between liquidity and profitability of manufacturing firms in Nigeria. The study concluded that financial liquidity has helped to improve financial performance selected manufacturing firms in Nigeria. Also, that cash ratio has positive and significant effect on the profitability of manufacturing Firms in Nigeria. Thus, firms in the manufacturing industry should objectively try to reduce their bill receivable, so as to guide against waiting longer to collect from customers, for the purpose of increasing their profitability.
\end{abstract}

Keywords: financial liquidity, profitability, quick ratio, cash ratio and current ratio

\section{Introduction}

The term 'Liquidity' refers to the ability of a firm to meet its short-term maturing obligations within one year (Khan \& Safiuddinm, 2016). The Liquidity resources of a firm may be kept in various forms: cash in hand and cash at bank, reserves drawing power under a cash credit or overdraft arrangement and short term deposits. Cash balances in current account provide the highest degree of liquidity. A firm can maintain liquidity if it holds assets that could be shifted or sold quickly with minimum transaction cost and loss in value (Khan \& Safiuddinm, 2016). Maintaining an appropriate liquidity is the very vital part of any types of organisation for day to day operation (Patjoshi, 2016). Financial liquidity of an organisation means in what way effectively and quickly the current assets of the organisation can convert into cash. In all kinds of business, cash is the vital part, without cash business unit cannot be sustained as well as it cannot take the benefit of different opportunities. Retaining liquidity as well as proper liquidity management controls the financial performances and progress of an organisation. For maintaining liquidity, the organisation has to maintain proper level of working capital, as adequate or inadequate working capital will be a damaging situation to the smooth operations of the organization (Patjoshi, 2016). Liquidity of organisation is the ability to pay its current obligations and which can be measured by different financial ratios. The financial performance of an organisation depends upon the proper liquidity management and the capability to generate revenue in addition to profit. The financial performances of an organisation use to measure with different profitability ratios (Siegel \& Shim, 2000). The effective liquidity management of a company comprises proper planning and monitoring its current assets as well as current liabilities. Which will help the company's to minimize the risk by meeting their current obligations and can maximize the profit by avoiding unnecessary investment in current assets (Patjoshi, 2016). Several studies were made in order to observe the interaction between financial liquidity and profitability such as Lazaridis and Tryfonidis (2006) who found a relationship between liquidity management efficiency and profitability. Companies enjoy better pricing when they hold 
enough cash to purchase from suppliers and thus they may enhance their profit. So having enough liquidity also affects the profitability of the firm. Siddiquee and Khan (2008) observed that firms which are better at managing liquidity are found to be able to make cyclical moves to build competitive advantage. They are also better at generating fund internally and also face lesser trouble while seeking external sources of financing. Kaur and Silky (2013) and Malik and Ahmed (2013) founded that there is a negative association between quick ratio and return on assets. The study supports the trade-off theory of liquidity and profitability. Any increase in liquidity will cause a diminishing trend in asset utilization capability of the firm. Ajanthan (2013); Egbideet al. (2013) and Saleem and Rehman(2011) studied the relationship between liquidity and profitability. The studies revealed that there is a positive relationship between cash ratio and profitability. Ahmed (2013); Ajanthan (2013); Alavinasab and Davoudi (2013); Bolek (2013); Manyo and Ogakwu (2013); Ajao and Small (2012); Azam and Haider (2011); Haq, Sohail, Zaman and Alam (2011); and Rahman (2011) revealed that there is a significant positive relationship between financial liquidity and profitability. Bhunia, Khan and Mukhuti (2011) observed a mixed impact of liquidity on profitability during the investigation of the top four Steel companies in India. Results showed that current ratio of Tata Steel Ltd is positively associated with profitability, current ratio of Lloyds Steel Ltd is negatively associated with profitability, current ratio of Kalyani Steels Ltd is negatively associated with profitability and the current ratio of JSW Steel Ltd is positively associated with profitability. Meanwhile, Agha (2014) and Afeef (2011) found that there is no significant relationship exists between current ratio and profitability (ROA).Despite the plethora of the relationship between liquidity and profitability of manufacturing firms both in developed and developing countries including Nigeria, the outcome have not been consistent. However, this study examines liquidity and the profitability of manufacturing firms and also determines the relationship between liquidity and profitability in Nigeria manufacturing firms.

\section{Literature Review}

\section{Liquidity}

Dalgaard (2009) describes Liquidity as the degree to which an asset or security can be bought or sold in the market without affecting the asset's price. He further explains that a liquid asset is characterized by a high level of trading activity and plays a vital role in the functioning of financial markets. Markets are liquid when those who have assets holdings can sell them at prices that do not involve considerable losses so as to gain the finance they need to fulfill other commitments (Amihud, 2002). A business enterprise making no profit may be considered as sick but one having no liquidity will die soon. As a matter of fact, liquidity is a necessary condition (or a pre-requisite) for the very survival of a nonfinancial company. The liquidity position of a firm is generally analyzed with the help of some important ratios computed on the basis of different constituents of working capital either in isolation or in aggregate or both.

\section{Profitability}

Every business is most concerned with its profitability. Profitability is the ability to make profit from all the business activities of an enterprise (Njure, 2012). It shows how efficiently the management can make profit by using all the resources available in the market. One of the most frequently used tools of measuring profitability is profitability ratios. Profitability ratios show a company's overall efficiency and effectiveness. Profitability is related to the goal of shareholders of wealth maximization, and investment in current assets is made only if an acceptable return is obtained (Njure, 2012). While liquidity is needed for a company to continue business, a company may choose to hold more cash than needed for operational or transactional needs or for precautionary or speculative reasons. Managers of nonfinancial companies must ensure maximum return from the investments of their principal and therefore must ensure they invest resources in high yielding ventures other than holding excess investments in current assets. Janglani and Sandhar (2013) identified the following Measures of corporate profitability; two major types of profitability ratios are computed: profitability in relation to sales and profitability in relation to investment. Gross profit margins (GPM), net operating margin (NOM), return on assets (ROA), return on equity (ROE), and return on capital employed (ROCE) are the main measures of profitability. Therefore, profit is an absolute measure and profitability is a relative measure of efficiency of the operations of an enterprise.

\section{Empirical Review}

Alshatti (2014) investigated the effect of liquidity management on profitability in the Jordanian Commercial Banks from the period of 2005 - 2012. The study used investment ratio, quick ratio, capital ratio, and liquid assets ratio as liquidity indicators, while for the profitability indicator, return on equity and return on asset using descriptive and regression analysis. The study found that the increase in quick ratio and the investment ratio affect profitability positively. However, negative effect was found of capital ratio and liquid assets ratio on Jordanian commercial banks profitability.

Saravanan and Jayanthi (2016) examined the impact on governance of liquidity on profitability of selected textile industries in India from 2000-01 to 20014-15. Statistical tools used for the study is Descriptive statistics, ANOVA and 
Regression analysis. The findings of the study revealed that the overall profitability depends on the other financial indicators like liquidity, profitability, activity and financial leverage. On the basis of evaluation of financial performance and financial position of the sample companies, it is observed that the Liquidity and solvency position have to be improved.The study concluded that the performance of the Indian Textile companies is good.

Patjoshi (2016) examined liquidity management and financial performance of selected steel companies in India from the period of 5years (2010-11 to 2014-15). The collected data has investigated through the descriptive analysis, correlation; regression and different financial ratio analysis. The experiential examination using both the correlation and regression analysis reveal that liquidity ratios measure by current ratio, liquid ratio, inventory turnover ratio, current assets turnover ratio and current liabilities to total assets have significant relationship with profitability measured by operating profit margin, net profit margin, return on total assets and return on investment.

\section{Methodology}

\section{Model Specification}

The study measured profitability in terms of profit after tax. On the other hand financial liquidity was captured by Current Ratio, Quick Ratio, and Cash Ratio within a fiscal year (calculated as absolute difference between the end period value and start period value). Function and linear presentations of the model estimated in the study are given below:

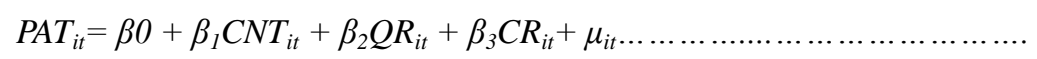

Where

$$
\begin{gathered}
\mathrm{PAT}=\text { Profit after Tax } \\
\mathrm{CNR}=\text { Current Ratio } \\
\mathrm{QR}=\text { Quick Ratio } \\
\mathrm{CR}=\text { Cash Ratio } \\
\beta 0=\text { intercept } \\
\beta_{1}, \beta_{2}, \beta_{3}=\text { coefficients } \\
\mu_{i t} \text { represent the error term, }
\end{gathered}
$$

\section{Source(s) of Data and Method of Analysis}

The study focused on five quoted manufacturing firms, the selected firms are: Guinness, Nigeria Beweries, PZ, Unilever and Nestle. The study relied heavily on secondary source of data. Secondary data used in the study was sourced from the Nigerian Stock Exchange fact books, annual reports of firms for a period of 10 years, spanning from 2007 to 2016. Data collated were analyzed using pooled Ordinary least square estimation, fixed effect estimation, random effect estimation Panel Unit Root, Panel Co-Integration Test, and Granger Causality.

\section{Data Analysis and Findings}

\section{Pooled Ordinary Least Square}

Table 1. Pooled OLS Result

\begin{tabular}{crrrr}
\hline Variable & Coefficient & Std. Error & t-Statistic & Prob. \\
C & 6.990712 & 0.086628 & 80.69782 & 0.0000 \\
QR & -0.168814 & 0.135040 & -1.250096 & 0.2176 \\
CR & 0.613505 & 0.257476 & 2.382765 & 0.0214 \\
CNR & -0.043636 & 0.028562 & -1.527760 & 0.1334 \\
\hline
\end{tabular}

$R$-square $=0.552788$, Adjusted $R$-square $=0.497535, F$-statistics $=2.765241$, Prob $(F$-stat $)=0.052448$

Source: Data Analysis (2018)

In Table 1, the R-squared $\left(\mathrm{R}^{2}\right)$ which is also known as the coefficient of multiple determination, measures the success of the regression in predicting the value of the dependent variable within the sample and tests the goodness of fit. It appears good with the value of 0.552788 (55.3\%) which implies that the variables such as quick ratio $(\mathrm{QR})$, cash ratio (CR) and current ratio (CNR) have 55.3\% variation in profit after tax (PAT). The results of other statistical tools reveal that the F-test and its probability value are 2.765241 and 0.052448 implying that the independent variables jointly can influence the dependent variable PAT that is the entire regression test is statistically significant while the adjusted R-square and the Durbin-Watson statistic are considered appropriate in this study five percent level of significance. From the result, the difference in beta coefficient of the variables representing financial liquidity variables shows different contributions to profit after tax (PAT). In this result, using the beta coefficient, the constant value is positive 
with the value of 6.990712 and p-value 0.000 . This means that when all variables are held constant, there will be a positive variation up to the tune of 6.990712 units in PAT. The pooled regression coefficient of quick ratio (QR) to PAT is -0.168814 and its P-values are 0.2176 which implies that QR has a negative and insignificant impact on profit after tax. Cash ratio (CR) to PAT has the coefficient value of 0.613505 and its P-values are 0.0214 which depicts that $\mathrm{CR}$ is positive and significant to explain PAT. Current ratio (CNR) shows a coefficient value of -0.043636 and with p-value of 0.1334 which implies that CNR is negative and insignificant to profit after tax.

\section{Panel Fixed Effect}

Table 2. Panel Fixed Effect Result

\begin{tabular}{ccccc}
\hline Variable & Coefficient & Std. Error & t-Statistic & Prob. \\
\hline C & 6.915952 & 0.049805 & 138.8618 & 0.0000 \\
CR & 0.014777 & 0.157578 & 0.093779 & 0.9257 \\
CNR & $6.86 E-05$ & 0.016193 & 0.004236 & 0.9966 \\
QR & 0.025528 & 0.083442 & 0.305934 & 0.7612 \\
\hline
\end{tabular}

R-square $=0.781687$, Adjusted R-square $=0.745302$, F-statistics $=21.48353$, Prob (F-stat) $=0.000000$

Source: Data Analysis (2018)

Table 2 shows the result of fixed effect estimation and it reveals that the R-squared (R2) value is 0.781687 that is $78.2 \%$, implying that the independent variables such as CR, CNR and QR have above 78\% variation in the dependent variable (PAT). However, the F-statistic value is 21.48353 and its p-value is 0.00000 indicating that the independent variables jointly can impact significantly in profit after tax (PAT). The Durbin-Watson reveals that there is no serial correlation in the variables. Nonetheless, the beta coefficient of constant is positive with the value of 6.915952 and its p-value is 0.0000 indicating that when all the independent variables are held constant, there will be a positive variation up to the tune of 6.915952 units in PAT and it is significant. Additional, the coefficient value of CR is 0.014777 and p-value is 0.9257 implying that $\mathrm{CR}$ has a positive coefficient but not significant to influence PAT. The coefficient value of CNR is 6.86E-05 and its p-value is 0.9966 meaning that CNR is positive and not significant to impact on PAT while the coefficient value of QR is 0.025528 with p-value of 0.7612 implying that QR has positive impact on PAT but not significant.

\section{Panel Random Effect}

Table 3. Panel Random Effect Result

\begin{tabular}{crcrr}
\hline Variable & Coefficient & Std. Error & t-Statistic & Prob. \\
\hline C & 6.959588 & 0.055230 & 126.0099 & 0.0000 \\
CR & 0.379774 & 0.145304 & 2.613657 & 0.0121 \\
CNR & -0.024989 & 0.015610 & -1.600858 & 0.1163 \\
QR & -0.094121 & 0.076482 & -1.230638 & 0.2247 \\
\hline
\end{tabular}

$R$-square $=0.581533$, Adjusted $R$ - square $=0.421633, F$-statistics $=1.361144$, Prob $(F$-stat $)=0.266465$

Source: Data Analysis (2018)

Table 3 presents the result of panel random effect as shown above. The constant coefficient value is 6.959588 and its p-value is 0.0000 , this indicates that when all variables are held constant, PAT will increase positively with the value of 6.959588 units and it is significant.However, the regression coefficient of CR on PAT is 0.379774 and its P-value is 0.0121, this indicates that CR has a positive and significant impact on PAT. Whereas, the regression coefficient of CNR and QR on PAT are -0.024989 and -0.094121 and their p-values are 0.1163 and 0.2247 respectively, indicating that both $\mathrm{CNR}$ and $\mathrm{QR}$ have negative impacts on PAT and they are not significant. The R-squared $\left(\mathrm{R}^{2}\right)$ value is 0.581533 (58.2), this shows that the independent variables explained about $58.2 \%$ of the variance in profitability of manufacturing firms in Nigeria. Lastly, the p-value of F statistics is 0.266465 , this implies that the independents variables jointly cannot influence PAT. 


\section{Hausman Test}

Table 4. Hausman Test

Test cross-section random effects

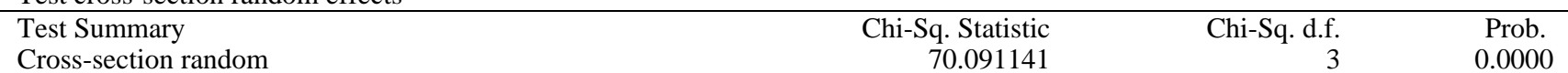

Source: Data Analysis (2018)

Table 4 presents the result of Hausman test. Meanwhile, the result shows the chi-square value of 70.091141 alongside the probability value of 0.0000 which implies that there is enough evidence to reject the null hypothesis of random effect model is appropriate. From the foregoing, it thus stands that among the two estimators (fixed effect model and random effect model) used for analysis in this study, fixed effect estimates presented in table 4 is most efficient and consistent estimate that can track the true nature of the nexus between liquidity and profitability.

\section{Conclusion and Recommendations}

In line with the findings of this study, it was established it was that financial liquidity has helped to improve financial performance selected manufacturing firms in Nigeria. Also, that cash ratio has positive and significant effect on the profitability of manufacturing Firms in Nigeria. The study equally established that there is no long-run relationship liquidity and profitability of selected manufacturing firm in Nigeria. It is recommended that the management of manufacturing should objectively try to reduce their bill receivable, so as to guide against waiting longer to collect from customers, for the purpose of increasing their profitability.

\section{References}

Agha, H. (2014). Impact of working capital management on profitability. European Scientific Journal, 10(1), 374-381.

Ajanthan, A. (2013). A Nexus between liquidity \& profitability: a study of trading companies in Sri Lanka. European Journal of Business and Management, 5(7), 65-76.

Ajao, O. S., \& Small, O. S. (2012). Liquidity management and corporate profitability: case study of selected manufacturing companies listed on the Nigerian Stock Exchange. Business Management Dynamics, 2(2), 10-25.

Akinbuli, S. F. (2006). Financial Accounting; Principles and Application. Lagos: BPrint Publishers.

Alavinasab, S. M., \& Davoudi, E. (2013). Working capital management and profitability of listed companies in Tehran stock exchange. Business Management Dynamics, 2(7), 1-8.

Alshatti, A. S. (2014). The effect of liquidity management on profitability in Jordanian Commercial Banks. International Journal of Commerce and Management, 2(4), 112-133

Amihud, Y. (2002). Illiquidity and stock returns: cross section and time series effects. Journal of Financial Markets, 5, 31-56. https://doi.org/10.1016/S1386-4181(01)00024-6

Azam, M., \& Haider, I. (2011). Impact of working capital management on firms' performance: evidence from NonFinancial Institutions of KSE-30 Index. Interdisciplinary Journal of Contemporary Research in Business, 3(5), 481-492.

Basno, A., \& Dardac, F. (2004). The Analysis of the Banking Liquidity Risk. Journal of International Business and Economics, 1(7), 95-98.

Beranek, W. (1966). Working capital management. Belmont, Calif.: Wadsworth Pub.

Bhunia, A., Bagchi, B., \& Khamrui, B. (2012). The Impact of Liquidity on Profitability: A Case Study of FMCG Companies in India. Research and Social practices in Social Sciences, 7(2), 44-58.

Bolek, M. (2013). Profitability As a Liquidity and Risk Function Basing on the New Connect Market in Poland. European Scientific Journal, 9(28), 1-15.

Dalgaard, R. (2009). Liquidity and stock returns: Evidence from Denmark. Journal of Financial Economics, 41, 41-64.

Dang, U. (2011). The CAMEL Rating System in Banking Supervision: A Case Study of Arcada University of Applied Sciences, International Business.

Egbide, B. C., Uwuigbe, O., \& Uwalomwa, U. (2013). Liquidity management and profitability of manufacturing companies in Nigeria. IOSR Journal of Business and Management, 9(1), 13-21. https://doi.org/10.9790/487X-0911321

Ejelly, A. (2004). Liquidity-Profitability Trade-off: An empirical Investigation in an Emerging Market. International Journal of Commerce \& Management 14(2), 48-61. https://doi.org/10.9790/487X-0911321 
Etale, L. M., \& Bingilar, P. F. (2016). Liquidity Management and Profitability: A Study of Selected Food and Beverage Companies in Nigeria. International Journal of Management Sciences, 7(4), 217-225.

Haq, I. U., Sohail, M., Zaman, K., \&Alam, Z. (2011). The relationship between working capital management and profitability: a case study of cement industry in Pakistan. Mediterranean Journal of Social Sciences, 2(2), 365-372.

Janglani S., \& Sandhar, S. K. (2013). A Study on Liquidity and Profitability of Selected Indian Cement Companies: A Regression Modeling Approach. International Journal of Economics, Commerce and Management United Kingdom, 1(1), 1-24.

Kaur, S. S., \& Silky, J. (2013). A study on liquidity and profitability of selected indian cement companies: A regression modeling Approach. International Journal of Economics, Commerce and Management, 1(1), 1-24.

Khan, M. M., \& Safiuddinm, S. K. (2016). Liquidity and profitability performance analysis of select pharmaceutical companies. international journal of science technology and management, 5(1), 167-177.

Kraus, A., \& Litzenberger, R. A. (1973). A State Preference Model of Optimal Financial Leverage .Journal of Finance, 911-922. https://doi.org/10.1111/j.1540-6261.1973.tb01415.x

Lamberg, S., \&Valming S. (2009). Impact of Liquidity Management on Profitability - a study of the adoption of Liquidity in a financial crisis. Master Thesis, Umea School of Business, Umea University.

Lazaridis, J., \& Tryfonidis, D. (2006). Relationship between working capital management and profitability of listed companies in the Athens Stock Exchange. Journal of Financial Management Analysis, 19, 26-35.

Malik, Q. A., \& Ahmed, S. F. (2013). Idiosyncratic effect of liquidity management strategies on corporate performance valuation-A study of Chemical Industry. World Applied Sciences Journal, 28(1), 114-119.

Manyo, T. S., \& Ogakwu, V. N. (2013). Impact of Liquidity on Return on Assets of Firms: Evidence from Nigeria. International Journal of Management \& Information Technology, 6(3), 885-894. https://doi.org/10.24297/ijmit.v6i3.728

Myers, S. C., \& Majluf, N. S. (1984). Corporate financing and investment decisions when firms have information that investors do not have. Journal of Financial Economics, 13(2), 187-221. https://doi.org/10.1016/0304-405X(84)90023-0

Neto, A. (2003). Finanças Corporativas e Valor. São Paulo: Atlas.

Njure, K. C. (2012). The relationship between liquidity and profitability of nonfinancial companies listed in Nairobi Securities Exchange.

Pandey I. M. (2005). Financial Management, New Delhi, India, Vikas Publishing House.

Panigrahi, A. (2013). Liquidity Management of Indian Cement Companies - A Comparative Study. IOSR Journal of Business and Management (IOSR-JBM), 14(5), 49-61. https://doi.org/10.9790/487X-1454961

Patjoshi, P. K. (2016). A study on liquidity management and financial performance of selected steel companies in India. International Journal of Advanced Information Science and Technology, 5(7), 108-117.

Peavler, R. (2009). Cash Management is Important for Your Small Business.

Rehman, M. M. (2011). Working capital management and profitability: A study on textiles industry. ASA University Review, 5(1), 115-132.

Shapiro, A. C. (2006). Multinational financial management.8th edition. Boston: Wiley, John \& Sons.

Shin, H. H., \& Soenen, L. (1998). Efficiency of working capital management and corporate profitability. Financial Practice and Education, 8(2), 37- 45.

Siddiquee, M., \& Khan, S. M. (2008). Analyzing Working Capital Performance: Evidence from Dhaka Stock Exchange (DSE) Ltd. The Journal of Nepalese Business Studies, 3(1), 37-48

Siegel, J. G., \& Shim, J. K. (2000). Financial Management.Barron's Educational Series.

Vishnani, S., \& Shah, B. K. (2007). Impact of Working Capital Management Policies on Corporate Performance -An Empirical Study. Global Business Review, 8, 267. https://doi.org/10.1177/097215090700800206

\section{Copyrights}

Copyright for this article is retained by the author(s), with first publication rights granted to the journal.

This is an open-access article distributed under the terms and conditions of the Creative Commons Attribution license which permits unrestricted use, distribution, and reproduction in any medium, provided the original work is properly cited. 